\title{
Üniversite Öğrencilerinin Sosyal Medyayı Algılama Biçimlerinin Yaptıkları Afiş Tasarımlarına Yansımaları: Bir Vakıf Üniversitesi Örneği*
}

\section{The Reflections of University Students' Social Media Perceptions on Poster Design Made by Them: The Example of a Foundation University}

\section{Hümeyra Adam}

Öğr. Gör., Yozgat Bozok Üniversitesi, Akdağmadeni Meslek Yüksekokulu, Grafik Tasarımı Bölümü email: adamhumeyra@gmail.com (DORCID ID: https://orcid.org/0000-0001-8013-185X

\author{
Çağrı Gümüş \\ Doç. Dr., KTO Karatay Üniversitesi, Güzel Sanatlar ve Tasarım Fakültesi, Grafik Tasarım Bölümü \\ email: cagrigumus79@gmail.com (DORCID ID: https://orcid.org/0000-0001-5901-9708
}

* Bu çalışma, KTO Karatay Üniversitesi Sosyal Bilimler Enstitüsü’nde yapılan “Üniversite Öğrencilerinin Sosyal Medyayı Algılama Biçimlerinin Yaptıkları Afiş Tasarımlarına Yansımaları: Bir Vakıf Üniversitesi Örneği” adlı yüksek lisans tezinden türetilmiştir.

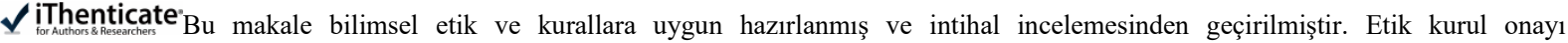
gerektirmemektedir.
\end{abstract}

Atıf (APA 7)/To cite this article

Adam, H., \& Gümüş, Ç. (2021). Üniversite öğrencilerinin sosyal medyayı algılama biçimlerinin yaptıkları afiş tasarımlarına yansımaları: Bir vakıf üniversitesi örneği. Atatürk Üniversitesi Güzel Sanatlar Enstitüsü Dergisi, 27(47), 424-442. https://doi.org/10.35247/ataunigsed.969099

Makale Gönderim Tarihi/Received: 09/07/2021

Makale Kabul Tarihi/Accepted: 24/10/2021

Makale Yayın Tarihi/Published: 28/10/2021

Research Article / Araștırma Makalesi

$\ddot{O} z$

Bireyler duygu, düşünce ve deneyimlerini paylaşabilme, sevdiği kişilerden haber alma ve yeni bilgiler öğrenebilme amaciyla iletișim kurarlar. $\mathrm{Bu}$ nedenle tüm bireyler varlıklarını sürdürebilmek için her an iletişim içerisindedirler. İnsanlık tarihinin başlangıcında ses ve görsel ögelerle gerçekleștirilen iletişimde jest, mimik ve sinyaller kullanılmaktadır. Bu dönemde insanlar mağara duvarlarına resimler çizerek, ateșten yararlanarak ve hayvan boynuzlarından sesler çkararak haberleşmektedirler. Yazının bulunması ile iletişim biçiminde değisiklikler yasanmıstır. Toplumlar anlaşabilecekleri yazı biçimi oluşturarak iletişim gereksinimlerini karşılamışlardır. 20. yüzyılda ise teknoloji alanında büyük gelişmeler yaşanmış ve iletişim, sanal ortamlarda gerçekleşmeye başlamışıtır. Teknoloji ve internette yaşanan gelişmeler birey ve toplumların bu alana yönelmelerine yol açmıștır. Bireyler haberleșme, bilgi edinme ve paylaşma gereksinimlerini sanal mecralarda karşılamaya baslamıslardır. Bu dönemde sosyal medya platformlarına yoğun ilgi başlamış ve daha önce gerçekleșen yüz yüze iletişim önem kaybetmeye başlamıştır. Her sosyal medya kullanıcısı sosyal medyayı aynı amaç doğrultusunda kullanmamaktadır. Araştırma, sosyal medya platformlarını ve kullanım amaçlarını ele alması açısından önem taşımaktadır.Araștırma kapsamında bir vakıf üniversitesinden seçilen 40 öğrenci, Facebook, Instagram, Twitter ve YouTube sosyal ağlarını ele alan 40 afiş tasarımı hazırlamıstır. Hazırlanan bu afișler arastırmanın konusunu oluşturmaktadır.Araştırma konusu hakkında geniş literatür taraması yapılmıștır. 40 üniversite öğrencisinin bulunduğu bir çalışma grubu olușturulmuștur. Öğrencilerden sosyal medya algılarını yansıtacak afiş̧ oluşturmaları ve ardından afiş̧erini değerlendirmeleri istenmiștir. Arasstırmada elde edilen bulgular değerlendirildiğinde çalışma grubunda en çok ele alınan sosyal medya platformunun Instagram olduğu ve sosyal medyanın en çok kimlik oluşturma amacı ile kullanıldığı sonuçlarına ulaşılmıştır.

Anahtar kelimeler: İletișim, Teknoloji, İnternet, Sosyal Medya, Afiş

\section{Abstract}

Individuals communicate to share their feelings, hear from ideas and experiences, and people they love and learn new information. Therefore all individuals are in touch at any moment to live a life.

At the beginning of humankind, gesture, mimic, and signals were used in communication with audio and visual elements. In this period people communicated by drawing pictures on the walls of the cave, using fire, and making sounds from the horn of an animal. There have been changes in the way of communication with the finding of the writing. Societies met a need for communication by creating a print format. In the $20^{\text {th }}$ century, there were extreme changes in the field of technology and people started to communicate in a virtual environment. Societies went towards that field because of developments in technology and the internet. Individuals started to meet a need for communication, learning information, and sharing in a virtual environment. In this period people started to be into social media platforms and face-to-face communication started to lose its importance. Every social media user doesn't use social media for the same purpose. The thesis is important in terms of dealing with social media platforms and their intended purposes.

The research includes 40 students chosen from any university, Facebook, Instagram, Twitter, YouTube users, and 40 design posters prepared by students. An extensive literature review was conducted on the subject of the research. A study group with 40 university students was created Students were asked to create a poster reflecting their social media perceptions and then evaluate the posters. When the findings obtained in the research are evaluated, it is concluded that the most discussed social media is used mostly to create identity.

Keywords: Communication, Technology, Internet, Social Media, Poster 


\section{Giriş}

Bireyler yaşadıkları her dönemde iletişim kurma gereksinimi içindedirler. İletişim bireyin sevdiklerinden haber alma, bilgi paylaşma, duygu ve düşüncelerini ifade etme etkinliğidir. Bu etkinlik doğumdan ölüme kadar olan süreci kapsar ve yalnızca işitsel olarak değil görseller aracılığıyla da gerçekleştirilebilir. İletişimin başladığı ilk yer ailedir. Bireyler doğumdan itibaren çevresine karşı ilgilidirler ve bu ilgi toplumsal ortamlarda varlığını gösterir. Erken yaşlarda çevreye gösterilen bazı tepkiler ilerleyen yıllarda paylaşma ve yardımlaşma gibi davranışların sergilenmesi ile daha anlamlı bir boyut kazanmaktadır. Daha sonraki zamanlarda bireyler sosyal yönden ve kişilerarası iletişimde kendilerini geliştirme ve bu ortamlarda kabul görme duygusu taşımaktadırlar (Erözkan, 2009, s. 57). Bireylerin iletişim içinde bulunduğu kişilerin sayısı arttıkça sosyal çevresinde de artış olur. Günlük yaşantıda bireyler her zaman iletişim halindedirler. Farkında olarak veya olmayarak çoğu zaman iletişim süreci gerçekleşmektedir. Birey, kimi zaman iletişimi başlatan kişi yani gönderici konumunda olurken kimi zaman da alıcı olarak rol almaktadır. Etkili iletişim kurabilen bireyler, karşılaştığı problemlerle baş edebilen, özgüven sahibi, problemlere daha objektif yaklaşabilen ve çözüm üretebilen bireylerdir. Etkili iletişim kuramayan bireylerde ise karşılaştıkları problemlerle baş etmekte zorlandıkları, güven ve kaygı problemi yaşadıkları görülmektedir. Bu kişiler problemi kendilerinde aramak yerine etraflarındaki olumsuzluklara odaklanarak, kendilerinden ve çevrelerindeki insanlardan sıkça yakınırlar (Erözkan, 2009, s. 57). İletişimin gerçekleştiği birçok kanal vardır ve sosyal yaşamın neredeyse tamamında çevredeki kişilerle iletişim içinde olunmaktadır. İletişimde kanal, iletişimin gerçekleştiği ortam olarak ifade edilebilir. Mesajlar alıcılara kanallar yardımı ile aktarılır. Kullanılan kanalın yapısı mesajın gönderilme şeklini belirler (Becer, 2015, s. 25). Bireyler mesajlarını iletmeye çalışırken grafik tasarımdan ve tasarım alanlarından yararlanırlar. Grafik tasarımda mesajlar, hedef kitlenin yapısına göre birbirinden farklı araçlar yardımı ile iletilmektedir. Bu süreçte kimi zaman afiş gibi basılı ilanlar kullanılırken kimi zaman da web sitesi gibi yayın türlerinden yararlanılır. İletişimde kullanılan kanalın seçimi çevrenin yapısı doğrultusunda belirlenmektedir (Ambrose ve Harris, 2012, s. 108). Grafik tasarım iletişiminde sıklıkla kullanılan afiş, karmaşıklıktan uzak, sade tipografi kullanımı ve görsel düzeni ile mesajın etkili ve hızlı bir biçimde hedef kitleye iletildiği bir reklam aracıdır (Şimşek Yükselbilgili, 2016, s. 5). Afiş bir tasarım ürünü olduğu için mesajı iletebilen unsurlarla beraber dekoratif ögelere de yer verilmektedir.

Birçok kişi, bireylerin bazı şeyleri anlama ve telaffuz etme yeteneklerinin doğuştan geldiğine inanırlar. Bu düşüncenin aksine iletişim öğrenilen bir faaliyettir ve iletişim becerilerinin çoğu sonradan edinilir. Bireyler olgunlaştıkça, iletişimin gerekliliğini ve hayattaki önemini daha fazla anlarlar (Becer, 2015, s. 11).

İnsanoğlunun varlığından itibaren gerçekleşen iletişim, 20. yüzyıldan sonra insanlar için vazgeçilmez bir etkinlik haline gelmektedir. Önceleri iletişim, sözlü ve yazılı olarak gerçekleşirken 20. yüzyıldan itibaren teknolojinin ilerlemesiyle beraber dijital mecralarda da varlığını göstermektedir. Teknolojik gelişmeler, bireylere yeni iletişim ortamları sunarak iletişimin birçok kanal üzerinden gerçekleşmesine, dönütün hızlı olmasına ve duygu, düşünce ve fikirlerin çeşitli araçlar ile kolayca aktarılmasına yol açmaktadır. İletişim teknolojilerinin gelişmesi ile özellikle internetin sıklıkla kullanılması, modern iletişimin en önemli destekçisi haline gelmiştir. İnternet 1970'lerde kullanılmaya başlanmış 1990'lardan sonra kullanıcı kitlesinde hızlı bir artış görülmüştü. 2000'li yıllara gelindiğinde internetle birlikte sosyal medya sıklıkla kullanılarak her toplumdan bireyleri ilgilendirecek konuma erişmiştir (Akıncı Vural ve Bat, 2010, s. 3349). İletişim yaşam boyunca gerçekleştirilen bir eylemdir ve iletişim kurma ihtiyacı kişiye göre farklılıklar göstermektedir. Yapısı gereği kişiler yaşamlarında var olan durumları diğer kişilerle paylaşmak ister. Bu paylaşımı da sıklıkla sosyal medya üzerinden gerçekleştirirler (Çakmak ve Müezzin, 2018, s. 197).

İnternet, kullanımındaki rahatlık sebebiyle bireylere istedikleri tüm bilgilere kolaylıkla erişebilme imkânı sunmaktadır. Bilgiye erişme imkânı sunduğu gibi alışveriş yapma, oyun oynama, eğlenme, sosyal medya kullanma ve iletişim kurma gibi birçok imkânı da bünyesinde barındırır. Bu durumun aksine internet tüketimi kontrol altında tutulmadığı takdirde olumsuz sonuçlara yol açmaktadır. Tüketim kültürü, bireylerin alışkanlıklarına, ihtiyaçlarına ve bağımlılıklarına göre değişkenlikler gösterebilmektedir. Teknolojinin meydana getirdiği durumlara hızla adapte olunması ile dijital medya, basılı medya gibi yayın ortamları için bir tehdit unsuru olmaktadır. Teknolojinin bir tehdit unsuru olarak görülmesi kişilerin interneti kullanım alışkanlıklarına ve internete bakış açılarına göre farklılıklar oluşturabilmektedir (Ambrose ve Harris, 2012, s. 32).

İnternet birçok mecraya erişebilme firsatı sunmasına rağmen en çok talep gören iletişim ortamlarından birinin sosyal medya olduğu söylenebilir. Sosyal medya birçok amaçla kullanılabilmektedir. Bazı insanlar duygu ve düşüncelerini daha rahat ifade etme amacı ile kullanırken bazıları gün içerisindeki aktivitelerini paylaşmakta ve bazıları ise ekonomik kazançlarını sosyal medya üzerinden sağlamaktadırlar. Yeni kişiler tanımaya, yeni yerler görmeye ve birçok bireyle aynı anda kolaylıkla iletişim kurmaya olanak sağlayan sosyal medya bireylerin sosyalleşmesine sağlar. Sosyal medyanın bu denli sıklıkla kullanılması yüz yüze iletişimin gün geçtikçe azalarak yerini sanal ortamlarda gerçekleşen iletişim platformlarına bırakmasına neden olmaktadır. Akıllı telefonların artması ve internetin yaygınlaşması sonucunda sosyal medya kullanıcıları sayısında hızlı bir artış görülmektedir. 
Özellikle Instagram, Facebook ve Twitter aktif olarak kullanılmakta ve yüz yüze iletişimin önüne geçmektedir (Bahar, 2018, s. 2-3).

Günümüzde sosyal medya kullanımı, hayatın her anında karşılaşılan bir etkinliktir. İnsanlarda merak duygusunu tetikler ve bunun sonucunda bireyler günün her saatinde zaman kısıtlaması olmaksızın sosyal medya hesaplarına bakma ihtiyacı duyarlar. Bireyler bu platformlarda düşüncelerini özgürce ifade edebilmekte, müzik, görsel gibi paylaşımlarda bulunmakta, özel hayatlarını ve kişisel bilgilerini istedikleri gibi yayınlayabilmektedirler. Kişisel yaşantılara ait bilgiler sosyal medya aracılığıyla aktarılabilmektedir. Bireyler doğum tarihini, doğum yerini, hobilerini ve mesleğini paylaşarak ortak noktaları olan kişilerle iletişim kurma imkânı bulabilmektedirler. Bireyler yüz yüze iletişimde bu bilgileri rahatlıkla paylaşamazken sosyal medya platformları ile herhangi birinin merak etmesini beklemeden kişisel bilgilerini paylaşabilmektedir. Sosyal medyada bireyler paylaşım yaparken aynı zamanda diğer paylaşımlar aracılığıyla bilgi sahibi olabilmektedir (Fidan ve Acar, 2016: 67-68). Sosyal medya kullanımı bireylerin, hatta toplumun davranışlarında değişiklikler meydana getirebilir ve bunun yanı sıra sosyal medya aracılığı ile diğer bireylerin de davranışlarında değişiklikler oluşturulabilir. Bu durum sosyal medyanın avantajlarından biri olarak ifade edilebilmektedir. Günümüzde sosyal medya kullanıcılarının artmasının ve sosyal medya platformlarının hızla yayılması sonucunda platformların kontrol edilebilirliğini zorlaştırmaktadır (Akıncı Vural ve Bat, 2010, s. 3352).

Sosyal medya bireyler için ekonomik ve sosyal imkanları içinde barındırmaktadır. Platformların birçok imkânı barındırması ve bireyleri eğlendirmesi sonucu sosyal medyada geçirilen zaman fark edilmemekte ve kontrol altında tutulamamaktadır. Sosyal medya kullanıcıları zaman içerisinde bağımlı hale gelerek yalnızlaşmakta ve profillerini gerçekten uzaklaşarak olmak istedikleri şekilde düzenlemektedirler. Bu durum kişilik gelişimini etkilemektedir. İnsanların olduklarından farklı bir karaktere bürünmeleri sosyal medya kullanıcılarını güvenilmez göstermektedir (Bahar, 2018, s. 3-4). Sosyal medyanın olumlu birçok özelliği olmasına karşın bireyler kimi zaman bu özellikleri olumsuz yönde kullanmaktadırlar. Diğer bireylerin paylaştıkları fotoğraflar veya kişisel bilgiler istismar edilmekte ve bireyler sosyal medya platformlarında bulunan mesaj bölümünden sözlü tacize uğramaktadırlar. Bazı kullanıcılar ise duygu düşüncelerini bu mecralarda daha rahat ifade etmekte ve bazen kontrolsüz, sınır tanımayan eleştirilerde bulunabilmektedir.

"Sosyal medya için dünya çapında rakamsal bir değerlendirme yapıldığında şöyle bir tabloyla karşılaşılmaktadır:

- Dünya üzerinde her üç kişiden ikisi sosyal ağları ziyaret etmektedir.

- Her gün Youtube'ta 100 milyon video izlenmekte ve her dakika 20 saatlik video yüklenmektedir.

- Her gün Facebook üzerinde 8 milyar dakika geçirilmekte ve 285 milyon adet içerik paylaşılmaktadır.

- 14 milyondan fazla kullanıcıyla Türkiye Facebook’ta en aktif 3. ülke.

- Türkiye, Avrupa'nın internette en çok zaman geçiren ülkesi durumundadır.

- Friendfeed'in Dünya'da en popüler olduğu ülke Türkiye.

- 350 milyon aktif kullanıcısı ile Facebook bir ülke olsaydı Çin ve Hindistan'dan sonra dünyanın en kalabalık 3. ülkesi olurdu" (Akıncı Vural ve Bat, 2010, s. 3352-3353).

Ülkemizde ve dünyada sosyal medyanın bu denli fazla kullanılması sosyal medyanın iletişim, eğlence ve bilgi edinme gibi birçok amaca hizmet etmesinden kaynaklanmaktadır. Teknolojinin ve internetin hızla yayılım göstermesi bireylerde internet üzerinden iletişim kurma arzusu oluşturmuştur. Sosyal ağlar aracılığı ile insanlar kendi profillerini oluşturarak, aynı mekânda bulunmayan fakat aynı ağda yer alan birçok kişiyle etkileşimde bulunmaktadır.

Birçok kategoriye sahip olan sosyal medya, üretici ve tüketici konumundaki kullanıcılara çeşitli formatlarda içerik oluşturma ve paylaşma imkânı tanıyan sanal bir ortamdır (Zinderen, 2020, s. 219).

Sosyal ağ; bir grup insanın kaynak ve verileri paylaşarak istenilen sonuçları elde etmek için etkileşimde bulundukları web tabanlı sistemdir. Sosyal ağ kullanıcılara bilgiyi üyeler arasında paylaşma firsatı sunarak bilginin yayılmasını sağlar (AkıncıVural ve Bat, 2010, s. 3355-3356). İnsanlar sosyal medyayı duygu, düşünce, fikir ve deneyimlerini ifade etmek, bilgi edinme, paylaşmak, eğlenmek ve boş zamanları geçirmek gibi amaçlar için kullanırlar. Kurumların sosyal medya kullanma amaçları ise ürün ve hizmetlerini tanıtarak hem kurumsal imajlarına katkı sağlarlar hem de hedef kitlelerinin büyütebilirler.

İnsanlar sosyal medya ağlarından herhangi birine katılırken ilk olarak kendilerine bir profil oluştururlar. Kişisel bilgilerin yer aldığı bu profille tanıdığı veya arkadaş olmak istediği kullanıcılara arkadaşlık istediği göndererek etkileşime girer. Kullanıcılar, kimi zaman bir paylaşımda bulunur veya paylaşımları beğenip yorum yaparak varlıklarını gösterirler. 
Özellikle iletişim teknolojilerinde yaşanan gelişmeler sosyal medyayı toplumun vazgeçilmez bir parçası durumuna getirmiştir. Çağımızda sosyal medya iletişimde en yaygın olarak kullanılan ortamlardan biri olarak kullanılmaktadır. Web 2.0 tabanlı teknoloji ile, sosyal medyanın oluşumu başlamaktadır. Bloglar, sosyal ağlar, fotoğraf ve video paylaşma platformları sosyal medyanın kapladığı başlıca alanlardır. Sosyal medya kullanıcılara istedikleri içeriği zorlanmadan yükleyerek zaman ve mekân kısıtlaması oluşturmadan paylaşma imkânı sunar (Fidan ve Acar, 2016, s. 65). Kullanıcılar sosyal ağlarda profillerinde bilgilerini paylaşabilir, konumlarını açık bir şekilde belirtebilirler. Özellikleri birbirlerine benzeyen veya aynı konumda bulunan kullanıcılar etkileşimde bulunabilir, yeni arkadaşlıklar edinebilirler.

Web 2.0 siteleri ile kullanıcılar içerik oluşturarak sosyal etkileşim sağlarlar. Bu bağlamda Web 2.0 siteleri sosyal medya şeklinde tanımlanmaktadır. Sosyal medya kullanıcıların tek veya çift yönlü etkileşimlerine olanak sağlamaktadır (Çiftçi, 2018, s. 422). Sosyal medyanın sunduğu mesajlaşma özelliği ile kullanıcılar çevrim içi veya çevrim dışı olarak birbirleri ile mesajlaşabilirler.

Solis sosyal medyayı aşağıda belirtilen beş aşamada ifade etmektedir.

- Medyanın sosyalleşmesi yararına kullanılan bir mecra,

- Kişilerarası iletişimin oluşumunu kolaylaştıran çevrim içi ağlar,

- Bireylerin çevreleriyle etkileşimde olmasını sağlayan,

- İşbirliği oluşturan,

- Etkinin çevreye yayılmasını kolaylaştıran durum ve ayrıcalık (Kuyucu, 2014, s. 64).

Sosyal medya bireylere haberleşme bilgi edinme ve paylaşma gibi imkanları sağlayarak karşılıklı etkileşimde bulunulan web siteleri ve çevrimiçi platformlar için kullanılan bir terimdir (Çakmak ve Müezzin, 2018, s. 197). Günümüzde toplumların gerçek yaşamı sanal ortamlarda arama ihtiyaçları gün geçtikçe artış göstermektedir. İnternete olan erişimin yaygınlaşması ile neredeyse her birey, sosyal medya platformlarında yer alarak sosyal medyanın sunduğu olanaklardan yararlanmaktadırlar.

Genel olarak sosyal medya, iletişim gerçekleştirmek için internetin kullanılmasıdır. Böylelikle kullanıcılara neredeyse istedikleri her şeyi yapabilmeleri için imkân ve alan sunar. Kullanıcılar bu alanlarda paylaşmak istedikleri durumları geniş kitlelere duyurabilmektedirler (Fidan ve Acar, 2016, s. 65).

\subsection{Sosyal Medya Kullanımının Bireylere Etkileri}

Sosyal medya kontrollü kullanıldığında kullanıcılarına birçok olanak sağlamasına rağmen çoğu kullanıcı kendini sosyal medya konusunda sınırlandıramaz ve yalnızca boş olduğu vakitlerde değil işlerinin olduğu zamanlarda bile önceliğini sosyal medyaya verir.

Akıllı telefonlar birçok olumlu özelliği sunup yaşamı kolaylaştırmasına karşın zaman içerisinde olumsuz özelliklerin de yaşanmasına neden olmaktadır. İnternet erişiminin yaygınlaşması kişinin çevresiyle olan iletişimini gerçek yaşamdan uzaklaştırarak olumsuz yönde etkilemektedir. Bireyler sosyal ortamlarda bile sosyal medya veya herhangi bir internet ağına erişerek toplumdan uzaklaşırlar. Bu durum bireylerin yalnızlaşmasına yol açar (Arslan, 2019, s. 67). Telefonuyla sürekli vakit geçiren bireyler sosyal çevrede yaşanan olaylardan, konuşulan konulardan ve paylaşılan duygulardan uzaklaşarak kendilerini soyutlarlar.

Sosyal ağlarda paylaşılan fotoğraf, müzik, video, metin gibi içerikler bireylerin kimlik oluşturmalarına ve oluşturdukları kimlikleri yaymaya yöneliktir. Sosyal medyada kullanıcıların profil oluşturmaları fotoğraf paylaşmaları ve arkadaş edinmeleri kendi benliklerini diğer kullanıcılara sunma isteğinden gerçekleşmektedir (Şimşek, 2019, s. 13). İnsanoğlu yapısı gereği beğenilme arzusu içindedir. Sosyal paylaşım ağlarında bulunan birçok insan farklı dış görünüşlere sahiptir. Kimi insan görünüşünü beğenirken kimisi de rahatsızlık duyar ve kendinde beğenmediği yerleri fotoğraflarda düzenleyerek paylaşır. Birçok kullanıcının yer aldığı fotoğraf paylaşma temeline dayanan Instagram'da kullanıcılar fiziksel ve maddi rekabet içerisinde bulunurlar. Bazı kullanıcılar gittiği mekanları, eğlence biçimi, tükettiği gıdaları ve dış görünüşünü vurgulayan paylaşımlarda bulunurlar. Bu durum birtakım kullanıcı da kendini yetersiz hissetme duygusuna yol açabilir.

Sosyal medya kendini ifade etmekte zorlanan bireyler için pek çok avantaj sağlamaktadır. Sosyal medya ile bireyler yüz yüze iletişimden uzaklaşarak sanal iletişime yönlenmektedirler. Bu durumda kullanıcılar kendileri daha rahat ifade edebilecekleri bir ortam edinirler (Bahar, 2018, s. 3). Yüz yüze iletişimde bireyler karşısındaki kişiye karşı utanma, heyecanlanma veya korkma gibi duygular hissederek kendini yeterince ifade edemeyebilir. Sosyal medyada iletişiminde bu durumun önüne geçilmektedir.

Bazı bireyler sosyal medyada kendilerini farklı kimlik bilgileri ile tanıtmaları, herhangi bir kısıtlama olmadan herkesle iletişim kurabilmeleri istenmeyen bazı sonuçlara sebep olabilir. Kendilerini farklı statüde ve kimlikte tanıtan bireyler zorbalıkta bulunabilir ve küçük yaştaki kullanıcıları rahatsız edebilirler (Arslan, 2019, s. 67). 
Özellikle küçük yaşta olan çocuklar için olan bu risk neredeyse tüm kadınların maruz kaldığı ve endişe duyduğu bir durumdur. $\mathrm{Bu}$ durumda sosyal ağların yetersiz güvenlik önlemleriyle kendini muhafaza edemeyen kullanıcılar için gerekli tedbirler ve sınırlamalar tarafından sağlanmalıdır.

Mekân sinırlaması tanımayan sosyal medya, mesafeleri yok ederek insanlara kendinden uzak olanlarla etkileşimde bulunma olanağı sağlamaktadır. Böylelikle kullanıcı özlediği biriyle görüşebilir ihtiyacı olan psikolojik gücü edinerek yalnızlık duygusundan uzaklaşabilir.

Konuşmak, üzüntü, mutluluk, heyecan gibi duyguları paylaşmak ve zor anlarına destek alma gereksinimi için bireyler sosyal medya ağları üzerinden durum güncelleyerek ihtiyaçlarına sanal ortamdan destek olacak kişilere ulaşırlar. Yapılan paylaşıma gelen yorumlar ve beğenilerle kullanıcılar kendilerini motive ederler (Fidan ve Acar, 2016, s. 65).

\section{Yöntem}

Araştırma betimsel modele dayalı nitel bir araştırma olarak yürütülmüştür. Bu kapsamda bir vakıf üniversitesinden seçilen 40 öğrenci araştırmanın çalışma grubunu oluşturmaktadır. Çalışma grubuna ait bilgiler Tablo 1 ve Tablo 2'de görülmektedir.

Tablo 1

Çalışma Grubunun Cinsiyet Dă̆ılımı

\begin{tabular}{ccc}
\hline & f & \\
\hline Cinsiyet & 28 & 70 \\
Kiz & 12 & 30 \\
Erkek & 40 & 100 \\
Toplam & & o \\
\hline
\end{tabular}

Araştırmaya katılan kişiler \%70 kı, \%30 erkek olmak üzere toplamda 40 kişidir.

Tablo 2

Çalışma GrubununYaş Aralı̆̆

\begin{tabular}{lccc} 
Yaş & Minimum & Maksimum & Ortalama \\
\cline { 2 - 4 } & 18 & 23 & 21
\end{tabular}

Araştırmada yer alan katılımcılar arasında en küçük yaş 18, en büyük ise 23 olup toplamda yer alan 40 katılımcının yaş ortalaması 21 'dir.

Araştırma kapsamında geniş bir literatür taraması yapılmıştır. Ayrıcaçalışma grubunu oluşturan 40 öğrenciden, Facebook, Instagram, Twitter ve YouTube sosyal ağlarını ele alan ve sosyal medya algılarını yansıtacak birer afiş̧ oluşturmaları istenmiştir. $\mathrm{Bu}$ doğrultuda hazırlanan 40 afiş tasarımını daha sonra öğrencilerin değerlendirmeleri istenmiştir.

\section{Bulgular ve Yorum}

\subsection{Yapılan Afiş Tasarımlarında En Çok Vurgulanan Sosyal Medya Platformu}

Tablo 3

En Çok Vurgulanan Sosyal Medya Platformuna İlişkin Bulgular

\begin{tabular}{cccccc}
\hline YouTube & Facebook & Instagram & Twitter & Genel & Toplam \\
\hline 4 & 2 & 25 & 6 & 3 & 40 \\
\hline
\end{tabular}

Çalışmada YouTube için 4, Facebook için 2, Instagram için 25, Twitter için ise 6 afiş çalışması yapılmıştır. 3 katılımcı herhangi bir sosyal medya ağını ayırt etmeden geneli kapsayan afiş çalışması yapmıştır. Toplamda 40 afiş tasarımı ortaya konmuştur. Ele alınan sosyal medya platformları arasından en çok vurgulanan ağ 25/40 sayı ile çoğunluğu oluşturan Instagram'dır.

\subsection{Yapılan Afiş Tasarımlarında Sosyal Medya Bağlamında Kullanılan Temalar}

Afiş tasarımları incelendiğinde katılımcıların sosyal medyayı farklı bakış açılarıyla ele aldıkları görülmektedir. Veri analizi sonucuna göre değerlendirildiğinde ö̆grencilerin bakış açılarına göre sosyal medya

- Düşünceleri ifade etme

- Günlük aktiviteleri paylaşma

- Eğlence

- Satış ve reklam

- Olaylara dikkat çekme

- Mesafeleri yok etme

- Bağımlılık

- Kimlik oluşturma temaları ile ele alınmıştır. 


\subsection{Yapılan Afiş Tasarımlarında Sosyal Medyaya Bakış Açıları}

Afişlerde yer alan temalar öğrencilerin bakış açılarına göre farklılıklar göstermektedir. Her tema için yapılan afiş tasarımlarından üç afiş incelenmiştir. Bunlar aşağıda belirtildiği gibidir:

\subsubsection{Düşünceleri İfade Etme}

\section{Afiş 1}

Emojilerle Ifade Etme

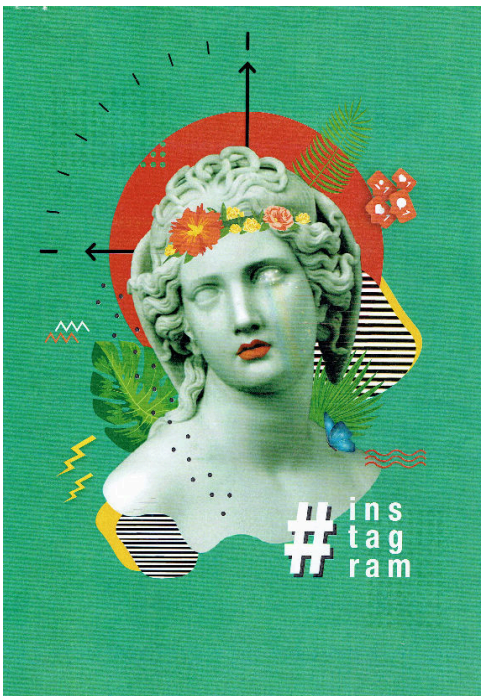

Öğrenci 1: "Gelişen ve değişen dünyada Çağımız insanı farklı mecralarda kendine yer bulmaktadır. Sosyal medya bireylerin kendilerini, ifade etme tarzlarını bize doğrudan veya örtük biçimlerde sunmaktadır. Sosyal medya araçlarından olan Instagram'da fotoğraf ve video paylaşma, başkaları ile iletişime geçme seçenekleri mevcuttur. Afiş tasarımında insanı sembol eden heykel kafası ve bu heykel üzerindeki kelebek, çiçek, bildiri vb.bulunmaktadır. Heykel ve emojilerin kullanımı renk ritimleri açısından dengede tutularak çalışma tamamlanmıştır. $\mathrm{Bu}$ gibi özelliklerden dolayı bireyler için vazgeçilmez boyuta ulaşan Instagram günlük hayatımızın ayrılmaz bir bütün olmuştur. Günün büyük bir bölümünde aktif kullanıcılar Instagram'da bulunduğu süre zarfında kendilerini ifade etmek için emojileri kullanmakta ve kendilerini rahat hissetmektedirler."

Afiş 1'de yer alan bildirim ikonları insanı simgeleyen heykel kafasının üzerinde yer alarak insanın zihninde bildirimlerin yer aldığını, başının etrafında bulunan saat kullanıcıların Instagram'a her an erişebildiklerini ifade etmektedir.

\section{Afiş 2}

Boş İçerik

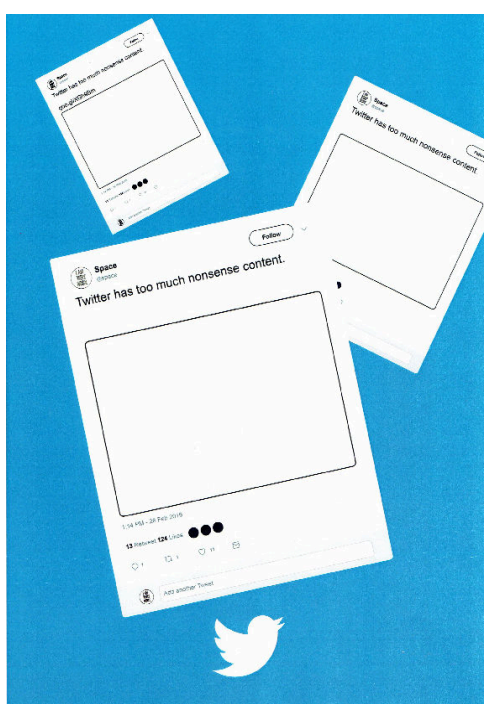

Öğrenci 2: "Sosyal medya mecralarında revaçta olan Twitter duygu ve düşünceleri ifade etmek için oluşturulmuş bir ağ olmasına karşın günümüzde genellikle konu dışı ve boş içerikler barındırmaktadır. Bazı 
kullanıcılar Twitter aracılığı ile düşüncelerini özgürce ifade edebilirler bazıları ise siyasi ya da mizah alanında mantıkdışı Tweetler atarak ağda boş içerikler oluşmasına yol açmaktadır. Tasarımda yer alan boşluklar Twitter'ı duygu ve düşünceleri ifade etmek için kullanmayan insanların gereksiz ve boş içeriklere yol açtığını simgelemektedir."

Afiş 2'de tasarım, rengini Twitter logosundan alan mavi zemin ve düşünceleri ifade etmek için kullanılması gerekirken içi boş halde duran tweet alanından oluşmaktadır. Tweet bölümünde "twitter has too much nonsense content” yazısı ile Twitter'ın gereksiz içeriklere sahip olduğu vurgulanmaktadır.

Afiş 3

Özgürlük

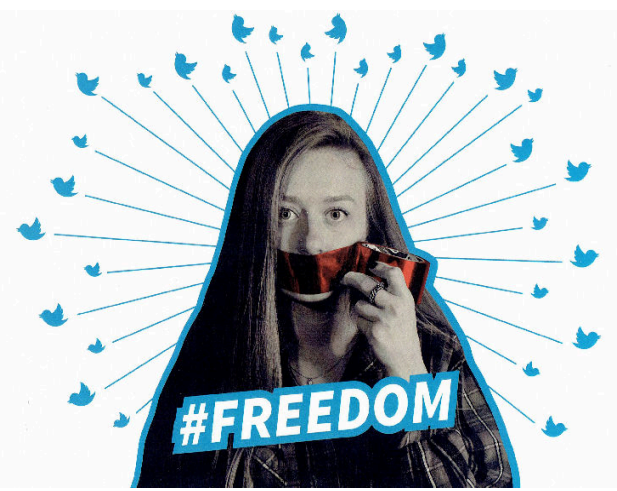

Öğrenci 3: "Çalışmada insanların düşüncelerini özgürce ifade edebileceği ortam olan Twitter ön plana çıkarılmıştır. Tasarımda yer alan birey düşünce hakkı elinden alınmış insanları ifade etmektedir. Bu birey Twitter ile düşüncelerini ve duygularını özgürce ifade edebilmektedir.”

Afiş 3'te konuşmasını engellemek için ağzı bantlanan bir birey yer almaktadır. Bireyin arkasında yer alan Twitter logoları ve üzerinde hashtag işareti ile yazılan "Freedom” düşünce özgürlüğünü ifade eder.

\subsubsection{Günlük Aktiviteleri Paylaşma}

\section{Afiș 4}

Mahremiyet

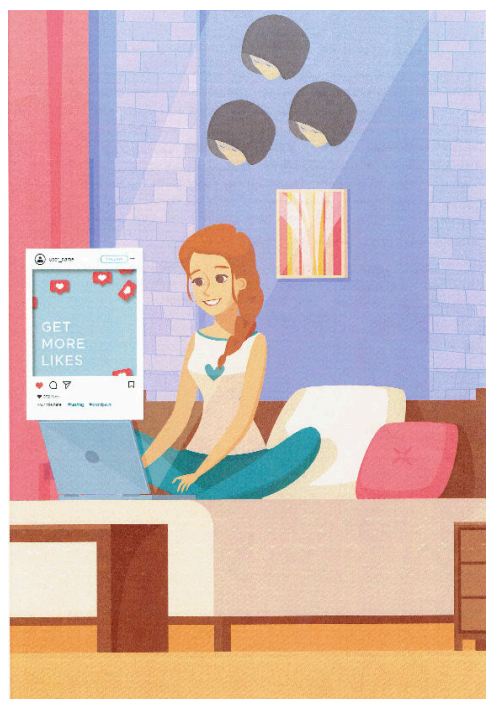

Öğrenci 4: "Instagram'ın bireylerin mahremiyet duygularını yok ettiğini düşünüyorum. Kapılarımızı kilitlerken, perdelerinizi kapatırken Instagram'da gönderilerle yaşamımızdaki her şeyi gösteriyoruz. Günlük hayatımızdaki olayları paylaşarak tanıdığımız veya tanımadığımız tüm insanlara hayatımızı sergiliyoruz."

Öğrenci afiş tasarımında evinde Instagram'da vakit geçiren bir bireyi çizmiştir. Ev bireylerin özel alanları olmasına rağmen kullanıcılar evde bile yaşadıklarını paylaşarak Instagram’ı aktif kullanmaktadırlar. Öğrenci Instagram'ı farklı bir bakış açısıyla da ele almaktadır. Mahremiyet duygusunun yanı sıra insanların birbirlerine benzerliğini de ele alan bu tasarımda Instagram ekranında yer alan "get more likes” yazısı ve afişin üst kısmında bulunan birbirinin aynısı olan üç baş, kullanıcıların daha fazla beğeni almak için birbirlerine benzedikleri ifade edilmektedir. 


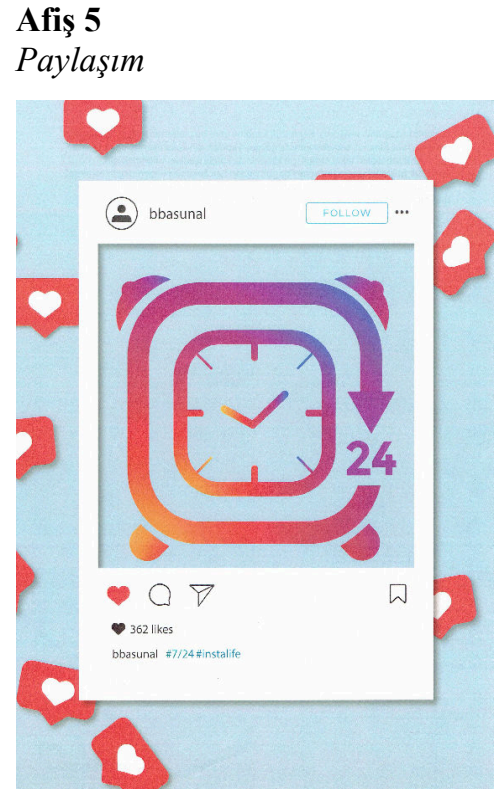

Öğrenci 5: "Instagram'ı seven ve kullanan kişi sayısı oldukça geniştir. Her kullanıcının bu platformda zaman geçirme nedeni farklı olabilir. Eğlenme, sevilen insanları takip etme, arkadaşlık kurma, içeriklere bakma gibi birçok nedenlerle kullanılsa da çoğu kullanacı gün içerisinde yaşadıklarını paylaşmaktadır. Bu kullanıcılar Instagram'da çok fazla zaman harcamaktadırlar. Bu nedenle çalışmamda Instagram'ı saat şeklinde tasarladım."

$\mathrm{Bu}$ afişte Instagram logosu gönderi içinde saat şeklinde tasarlanmıştır. Bu tasarımda Instagram'ın 24 saat içerisinde kısıtlama olmadan kullanıldığı gösterilmektedir. Kullanıcılar herhangi bir gönderi paylaşmasalar bile gün içerisinde sık sık Instagram'a girip bildirimlerini kontrol etme gereksinimi duymaktadırlar. Zeminde yer alan beğeni bildirimi işaretleri tasarımla bütünleştirilmiştir.

\section{Afiş 6}

Göz önünde yaşamak

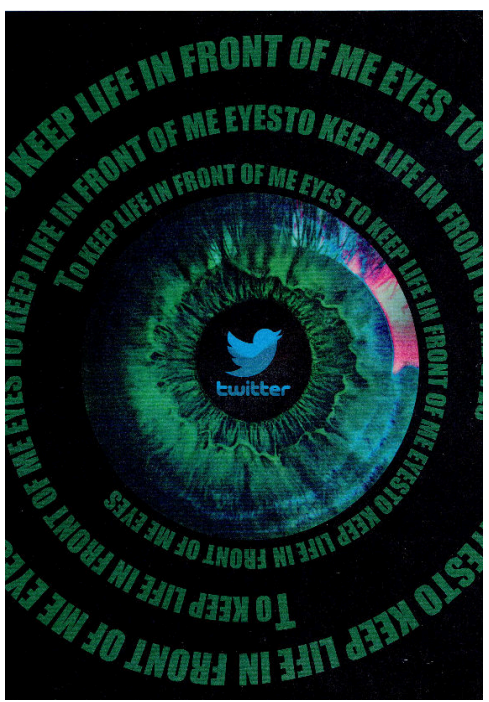

Öğrenci 6: "Duygu, düşünce, bilgi, deneyim ve etkinliklerin sosyal medyada yer alması, kullanıcıların yaşamlarını bu mecralarda paylaşmaları bireyleri göz önünde bulunmaya sürükler. Kullanıcılar hayatlarının her anında sosyal medyada paylaşırlar ve bu durumda kullanıcıların özel yaşamları yok olur.”

Başta tanınmış kişiler olmak üzere bazı kullanıcılar yaşamlarının her anını sosyal medyada paylaşma gereksinimi duymaktadırlar. Kimileri bu paylaşımı görsellerle yaparken kimileri de metinler aracılığıyla duygu ve düşüncelerini veya etkinliklerini takipçileriyle paylaşmaktadırlar. Bu kullanıcılar yaşamlarını başkalarına sergilerken diğer kullanıcılar tarafından göz önünde bulunmaktadırlar. Öğrenci afiş tasarımında göz görseli ne yer vererek etrafını çevreleyen "to keep life in front of my eyes" yazısı ile hayatı göz önünde tutma vurgusunu yapmıştır. Tasarımda Twitter logosunda yer vererek insanların Twitter' da başkalarının düşüncelerine ve görsellerine erişebildikleri vurgusunu göstermektedir. 


\subsection{3. Ĕglence}

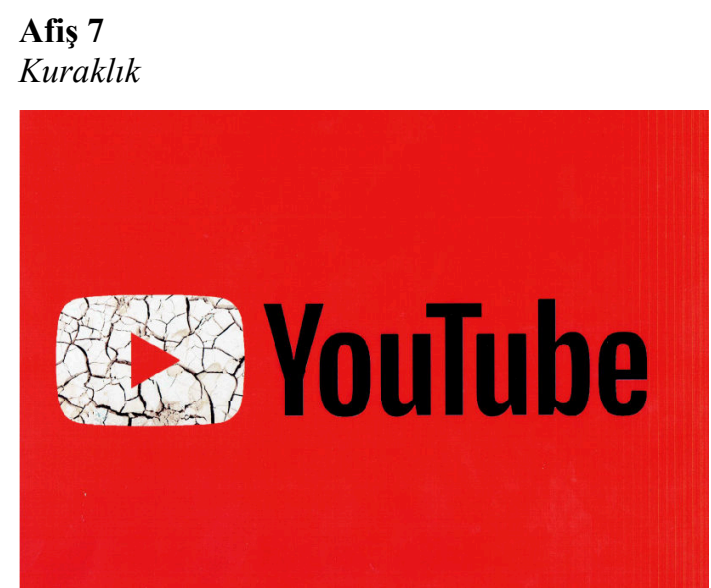

Öğrenci 7: “Tasarımda YouTube ile kuraklık kavramını birleştirmek istedim. Çünkü insanlar eğlenmek için YouTube'da dizi, film, futbol, oyun ve makyaj gibi videoları izlerler. Bireylerin taleplerinin bilgi edinmek yerine eğlenmeye yönelik olduğu bu platformda birçok videolar bulunmaktadır. Son dönemlerde bu durumun artış göstermesi bu konuyu ele almama neden oldu. Kuraklık kavramı benim için olan bir şeyin bitmesi yok olması değerinin kalmaması gibi düşünceleri çağrıştırıyor. YouTube'un eğlence için birçok video üretmesi yakın zamanda değerini kaybetmesine ve tükenmesine yol açacaktır."

YouTube'da birçok içerik üreticisi bulunmaktadır. Kullanıcıların videolarının izlenme oranlarına göre ekonomik gelir elde etmeleri birçok insanı bu mecraya yönlendirmektedir. İçerik üreticilerinin çok fazla olması ile YouTube'da değerli veya değersiz birçok video bulunmaktadır. Öğrenci Afiş tasarımında YouTube logosunu kuraklık ile birleştirerek YouTube'un bu karmaşıklık ve boş içerikler nedeni ile önem kaybedeceğine ve zaman içerisinde yok olacağına vurgu yapmaktadır.

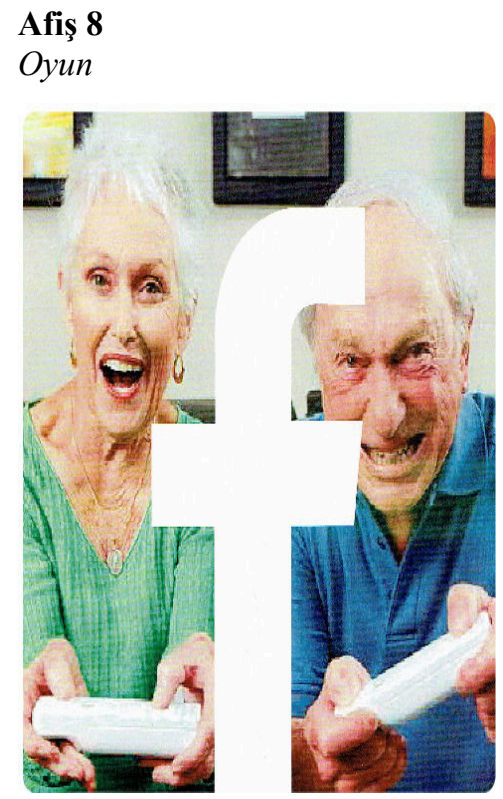

Öğrenci 8: "Benim için Facebook yaşlıların yer aldığı bir sosyal medya platformudur. Instagram ve Twitter gibi sosyal medya mecralarının çıkması ile Facebook geçmişte kalmıştır. Bu nedenle de yaşlıların tercih ettiği bir alan olmuştur. Yaşlılar Platformu genellikle oyun oynamak için kullanırlar.”

Facebook kullanıcılarına ağ üzerinden bazı oyunlara erişebilme imkânı sunmaktadır. Kullanıcılar Facebook arkadaşlarıyla veya tanımadığı kişilerle çevrimiçi oyun oynayabilmektedirler. Bu özelliği ile Facebook, diğer sosyal medya platformlarından farklılaşır. Genç kesimin Instagram ve Twitter'a yönelmesi ile Facebook özellikle yaşlıların kullandığı bir platform haline dönüşmüştür. Afiş tasarımı ile Facebook'un kullanıcı kitlesi olan yaşlılar ve diğer platformlardan farklı olan oyun özelliği vurgulanmıştır. Tasarımda Facebook logosunun mavi kısmı değiştirilerek oyun oynayan yaşlı bir çift fotoğrafı yerleştirilmiştir. 


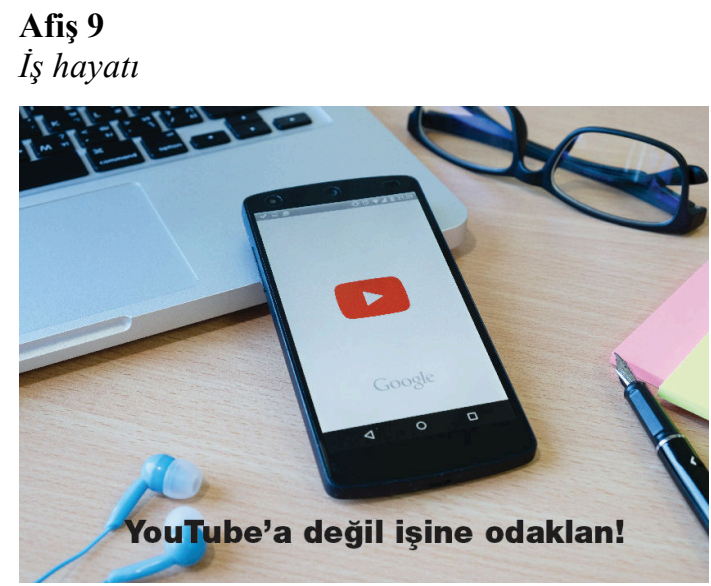

Öğrenci 9: "Benim için Youtube boş zamanlarımızı değerlendirmek ve eğlenmek için video izlediğimiz bir sosyal medya alanıdır. Fakat bazen iş yerinde, okulda veya önemli bir yerdeyken sorumluluklarımızı yerine getirmeyerek kendimizi YouTube'da gerektiğinden fazla vakit harcarken buluruz. Eğlenmek için kullandığımız bu platform böyle durumlarda yaşamımızı aksatmamıza neden olmaktadır."

Afiş 9'da öğrenci bazı kullanıcıların YouTube'da video izlerken işlerini aksattığı konusunu işlemiştir. Afiş tasarımında masa üzerinde duran bilgisayar, kalem, kâğıt ve gözlük objeleri masanın çalışma amaçlı kullanıldığını göstermektedir. Fakat masada yer alan telefonda YouTube'ın açık olduğu görülmektedir. Afişsi tasarlayan öğrenci tasarıma "YouTube'a değil işine odaklan!” yazısı ekleyerek eğlence için işlerini ihmal eden kullanıcılara uyarıda bulunmaktadır.

\subsubsection{Satış ve Reklam}

\section{Afiș 10}

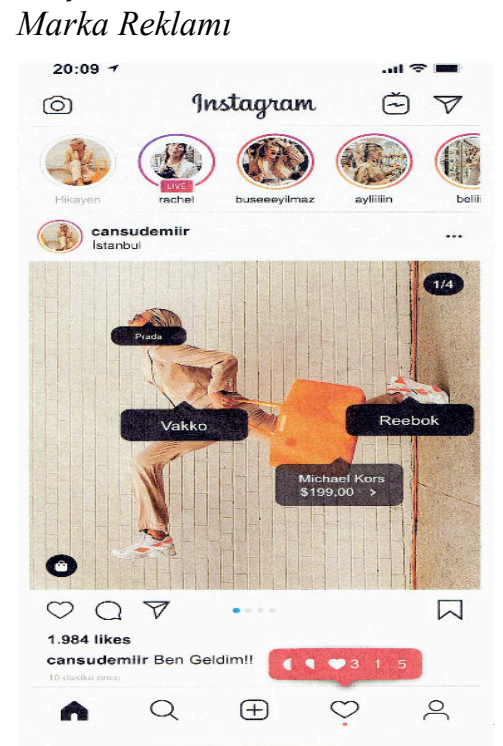

Öğrenci 10: “Günümüzde insanların olmazsa olmazı olan Instagram, diğer sosyal medya platformlarına oranla daha fazla reklam ve satış yapılan bir mecra haline gelmiştir. Takipçi ve beğeni sayıları fazla olan kullanıcılar geçmiş yıllarda fenomen olarak tanımlanırken günümüzde Influencer olarak anılmaya başlandı. Bu sayede Influencerlar çeşitli markalarla işbirliği yaparak profillerinde ürün tanıtarak ekonomik gelir elde ederler. Onları yakından takip eden hayranları ise paylaşım yapılan markalardan alışveriş yaparak markanın kazancını artırırlar. İlk başlarda kendilerine ait sayfa açıp Ürün tanıtımı yapan markalar daha sonra Influencerlarla Işbirliği yaparak satış sistemlerini değiştirdiler. Influencerlar ürünleri profillerinde paylaşıp üzerine markayı etiketleyerek kullanıcılar etiket aracılığıyla ürüne ve fiyatına erişsebilmelerini sağlarlar.”

Instagram kullanıcıları görsellerde yer alan etiketler sayesinde ürünü satın alabilecekleri sayfalara kolaylıkla ulaşabilmektedirler. Influencerların yapmış oldukları satış ve reklam yöntemiyle alışverişte yeni bir yöntem oluşturulmuştur. Instagram ana sayfasından oluşan afiş tasarımında ürün tanıtımının yer aldığı bir Influencera ait gönderi bulunmaktadır. Gönderide bireyin üzerinde yer alan kıyafet ve aksesuarlar etkilenerek ürünün markası veya fiyatı belirtilmiştir. Kullanıcılar etiketleri tıklayarak ürüne veya markaya kolayca ulaşabilir. 


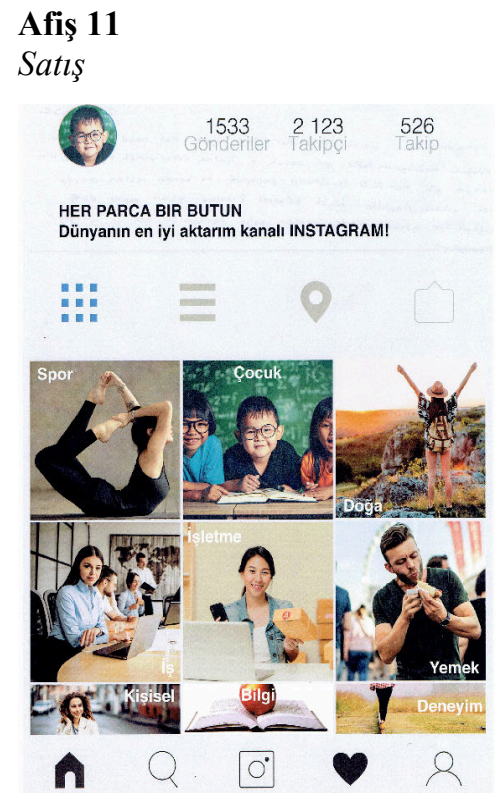

Öğrenci 11: "Instagram her alana uygun olan bir sosyal medya kanalıdır. Sağlık, spor, çocuk, iş, eğitim, işletme, doğa, yemek, kişisel blog, bilgi ve deneyim gibi her türlü paylaşımın gerçekleştiği bu kanalın reklam oranı oldukça yüksektir. Bu özelliği ile genellikle küçük bölgesel firmalara reklam yapma olanağı sağlamaktadır. Satış özelliğinin gün geçtikçe daha fazla önem kazanacağı ve yaygınlaşacağı düşüncesindeyim.”

Instagram profili tasarımında oluşturulan bu afişte, farklı kategorilere yer verilerek kullanıcıların ilgi alanlarına yönelebilecekleri ifade edilmiştir.

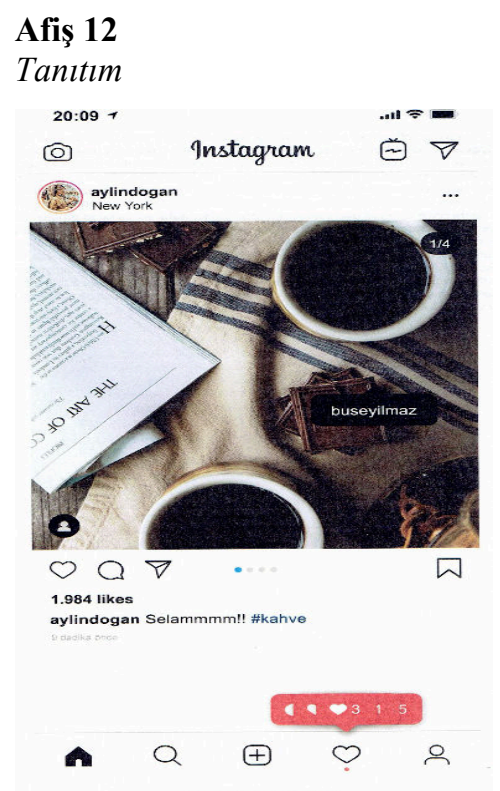

Öğrenci 12: "Instagram, takipçi sayısı fazla olan insanların yeni yerler ve ürünler tanıtmasıyla Influencer adı verilen yeni bir meslek grubunun oluşmasına yol açtı. Influencerlar sponsorlar sayesinde sürekli seyahat ederek aktivitelerini kullandıkları ürünleri tükettikleri gıdaları ve gittikleri mekanların tanıtımını ve paylaşımını yapmaya başladılar. Kullanıcılar bu sayede beğeni ve takipçi elde ederek daha geniş takipçi kitlesi elde ettiler. Böylelikle Influencerlar tanıtım yaparak sponsor ve gelir elde ettiler.”

Afişte 12'de yer alan “aylindogan” adına sahip kullanıcının Instagram gönderisinde kahve, çikolata ve dergi fotoğrafi yer almakta, bu fotoğraf konum ve etiketlerle desteklenmektedir. Kullanıcı gönderisini bir sohbet havası içinde oluşturarak hedef kitlesi ile etkileşimde bulunmayı amaçlamaktadır. Tasarımın alt kısmında belirtilen bildirimler, kullanıcının gönderilerine gelen etkileşimlerini göstermektedir. 


\subsubsection{Olaylara Dikkat Çekme}

Afiş 13

Kadraj

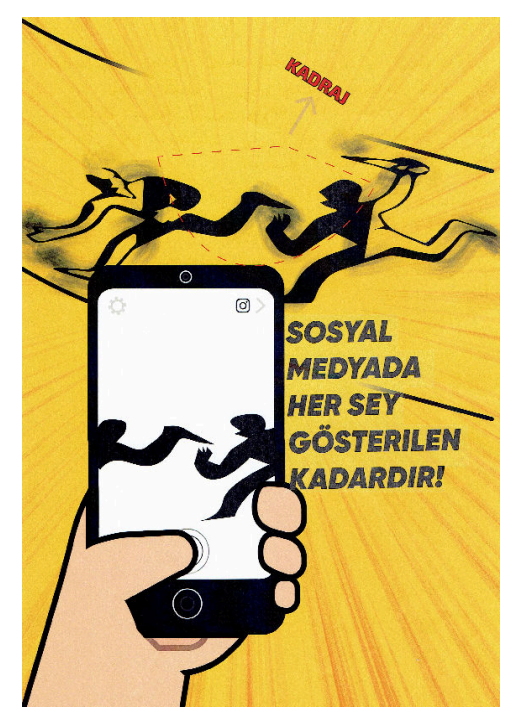

Öğrenci 13: "Sosyal medya toplumsal olaylara dikkat çekmek için kullanılan etkili bir yayın organıdır. Özellikle Instagram kullanıcıları tanık oldukları herhangi bir olayı hikâye olarak hesaplarında paylaşırlar. Bu durum bazen tamamıyla gerçeği yansıtsa da bazı durumlarda kullanıcının kadrajına göre gerçeği eksik yansıtabilir. Sosyal medyanın olayları var olduğu gibi yansıtmaması kullanıcıların üzerinde kötü algı oluşturabilir.”

$\mathrm{Bu}$ afişte bir Instagram kullanıcısı, bıçaklı bir tartışmanın gerçekleştiği olayı elindeki telefonla Instagram'ın hikâye bölümünden kadrajın alabildiği kadarını çekmektedir. Kullanıcı bu olayı tam olarak çekmeyerek gerçeği eksik bir biçimde takipçileriyle paylaşmaktadır. Afişte yer alan "Sosyal medyada her şey gösterilen kadardır!" söylemi ile olayların Instagram kullanıcısının çekimine göre değişkenlik gösterdiği vurgulamaktadır.

\section{Afiş 14}

Duyarsızlaşma

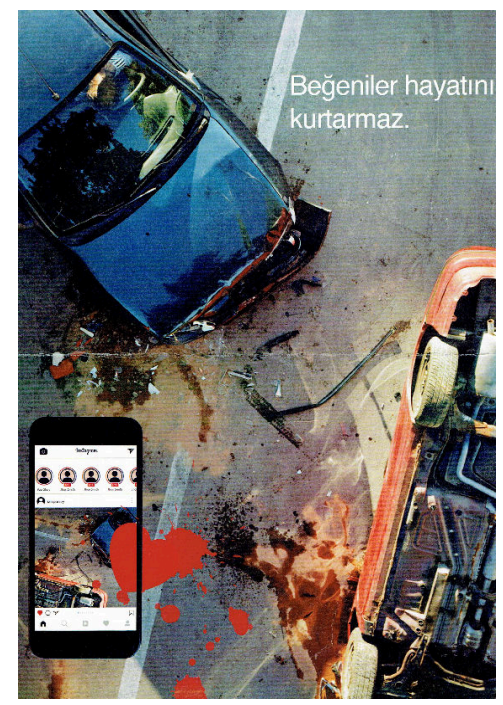

Öğrenci 14: "Bazı Instagram kullanıcıları yaşanan olayları hesaplarında hikâye veya gönderi olarak paylaşırlar. Fakat Instagram'ın bazı insanları önemli ve Hayati olaylara karşı duyarsızlaştırdığını düşünüyorum. Örneğin kaza veya intihar olaylarında insanlara yardım etmek yerine canlı yayın açmaları veya paylaşım yapmaları gibi bazı insanlar üzerinde olumsuz etki bırakır. Bunun yanı sıra kimi kullanıcilar trafikte yola odaklanmak yerine sosyal medya ile ilgilenerek kazalara sebep olabilmektedirler."

Bazı Instagram kullanıcıları yaşadıkları veya tanık oldukları büyük olayları paylaşarak beğeni, görüntülenme ya da takipçi kazanabileceklerini düşünürler. Bu nedenle yaşanan olay büyük sonuçlar oluşturmasına rağmen bireyler duruma müdahale etmek yerine bu durumu paylaşmayı tercih ederler. Afiş 14'te bir trafik kazasının gerçekleştiği an ve duruma müdahale etmeyen fakat kaza fotoğrafının Instagram'da paylaşıldığı bir hesap 
görülmektedir. Instagram kullanıcısı olaya müdahale etmek yerine anı yakalayıp beğeni elde etme peşindedir. Bu duruma tepki çekmek için afişte "beğeniler hayatını kurtarmaz" söylemi yer alır.

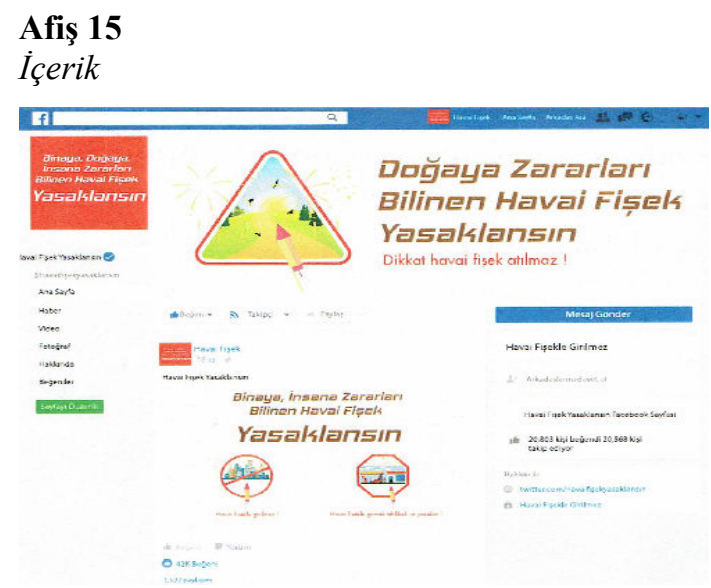

Öğrenci 15: "Sosyal medya kullanım amacına ve içeriklerine göre zararlı veya yararlı olabilir. Örneğin Facebook'ta kadına şiddete veya çocuk istismarına tepki göstermek için oluşturulan bir içerik bazı bireylerin ruhsal açıdan zarar görmesine yol açabilir. Bu nedenle sosyal medya paylaşılan içeriklerin dikkatli ve düşünülerek kullanılması gereken bir mecradır."

Afiş 15 'te toplumsal ve sosyal konulara dikkat çekmek için oluşturulan hesap ve gönderilerin olumlu sonuçlara yol açması için oluşturulmasına rağmen bazı durumlarda kullanıcıların ruhsal açıdan etkilenmelerine neden olabileceği belirtilmiştir. Tasarımda "Havai Fişekler Yasaklansın" isimli bir Facebook hesabı ele alınmıştır. Hesapta havai fişeklerin olumsuzluklarını belirten ve kullanımına tepki oluşturan görseller paylaşılmıştır. İlk bakışta olumlu bir amaç için oluşturulan bu hesabın bazı kullanıcılarda korku ve endişe gibi duygulara yol açabileceği görülmektedir.

\subsubsection{Mesafeleri Yok Etme}

\section{Afis 16}

Dünya İletişimi

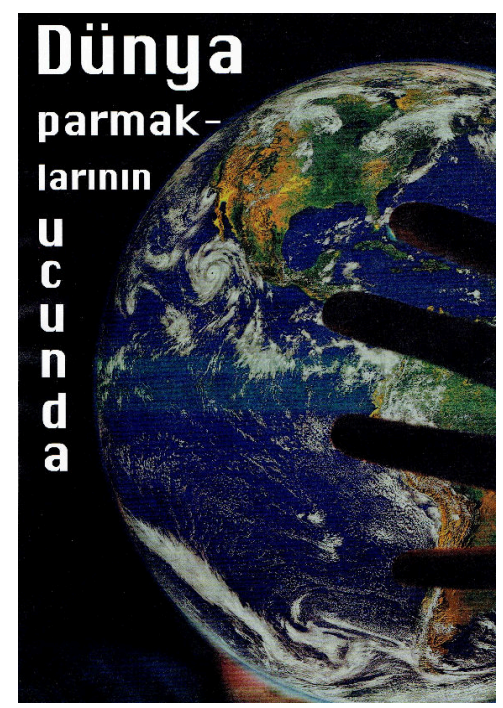

Öğrenci 16: "Instagram bütün dünya ile iletişim halinde olmamızı ve istediğimiz her an dünyanın her yerine ulaşabilmemizi sağlayan bir platformdur. Instagram aracılığı ile kendimizi veya işlerimizi herhangi bir çevrede daha kolay ve işlevsel bir biçimde duyurabiliriz."

Sosyal medya insanlara zamandan ve maddi harcamalardan kaçınarak istedikleri mesafedeki kullanıcılara ulaşabilme imkanını sunmaktadır. Kullanıcılar başarılarını ve yaptıkları işleri mesafeleri aşarak geniş kitlelerle paylaşabilirler. Afiş 16 'da el parmakları ve dünya görselleri ile kullanıcıların dünyanın herhangi bir yerine erişebildikleri vurgusu yapılmaktadır. Afişte yer alan "dünya parmaklarının ucunda” söylemi tasarımda yer alan görselleri açıklama niteliğindedir. 


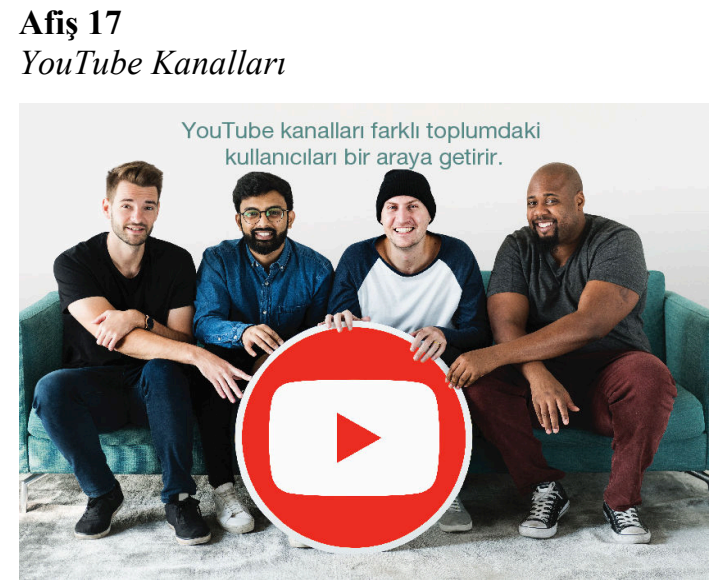

Öğrenci 17: "YouTube'da farklı ülkelerdeki kullanıcıların açtığı birçok kanal bulunmaktadır. Bazı konularda daha fazla bilgi elde etmek veya farklı bakış açılarını görmek için yabancı videoları da izleriz. Böylelikle farklı topluluklardaki insanlar aynı videoyu izleyerek ortak alanda bulunurlar. Bu durumda eğlenme, haber alma ve öğrenebilmek için mesafeler yok olur."

YouTube kanallarının mesafeleri yok ettiği düşüncesinin ele alındığı bu tasarımda farklı toplumlardaki bireylerin YouTube logosunu tutarak bir arada bulundukları fotoğraf kullanılmıştır. Burada YouTube'un birleştirici ve mesafeleri yok edici bir görev üstlendiği görülmektedir. Çalışmanın üst kısmında "YouTube kanalları farklı toplumdaki kullanıcıları bir araya getirir” açıklamasına yer verilmiştir.

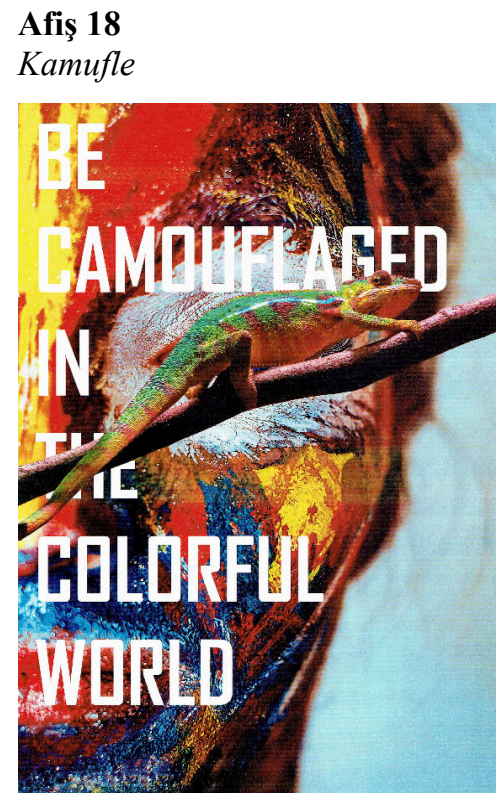

Öğrenci 18: "Instagram dünyanın dört bir yanında bulunan insanların bir arada olduğu uygulamadır. İnsanların fotoğraf çekip paylaştığ 1 , mesajlaştığı ve birbirlerini stalkladığı bir platformdur. Instagram aracılığı ile kullanıcılar herhangi bir mesafedeki bireylerin paylaştığı fotoğraf ve videolara erişebilir onlarla iletişim halinde bulunabilirler. Bazı kullanıcılar birçok farklı bireylerin olduğu bu mecrada kendilerini kamufle ederek diğer insanlarla paylaşımda bulunabilirler afiş tasarımında insanların kimliklerini gizleseler de iletişim halinde olabileceklerini vurguladim."

Afiş 18'de dal üzerinde duran bukalemun ve arkasında bukalemun gibi renkler taşıan insan görseli yeralmaktadır. Öğrenci bu tasarımda Instagram kullanıcılarını bukalemuna benzeterek yer aldıkları platform içerisinde kendilerini gizleyerek kimlik değiştirebildiklerini belirmiştir. Tasarımda "be camouflaged in the colorful world" yani renkli dünyada kamufle olmak metni yer almaktadır. 


\subsubsection{Bă̆ımlılık}

Afiş 19

Hayal Dünyasl

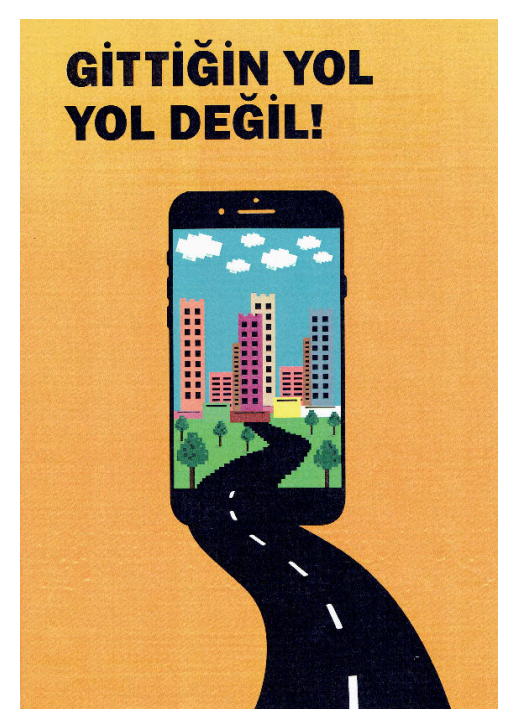

Öğrenci 19: “Sosyal medya yaşamımızı kolaylaştırırken bir yandan da gerçek hayattan alıkoyuyor. Teknolojinin günümüzde yaygınlaşması ile birlikte insanlar anın tadını çıkartmak yerine sosyal medyada paylaşım yapabilme çabası içine giriyor. Bunu yaparken yaşamlarına adeta pikselli bir kamerayla bakıyorlar. Yani gerçek yaşamdan çıkıp hayal alemine dönüyorlar. Yalnız bunu yaparken gerçek yaşamdan uzaklaşarak sosyal medya bağımlısı oluyorlar."

Öğrenci yapmış olduğu bu çalışma ile sosyal medyanın kullanıcıları gerçek yaşamdan uzaklaştırdığı konusunu ele almıştır. Tasarımda yer alan telefon ekranı hayal alemini, uzun yol ise sosyal medyanın gerçek yaşamdan hayal alemine yönelttiğini belirtir. Sosyal medyada kullanıcıları bu yolu geçerek gerçek yaşamdan uzaklaşır hayal alemine girerler. Afişin üst kısmında "gittiğin yol yol değil" cümlesi ile sosyal medya kullanıcıları uyarılmaktadirlar.

\section{Afiș 20}

Köle

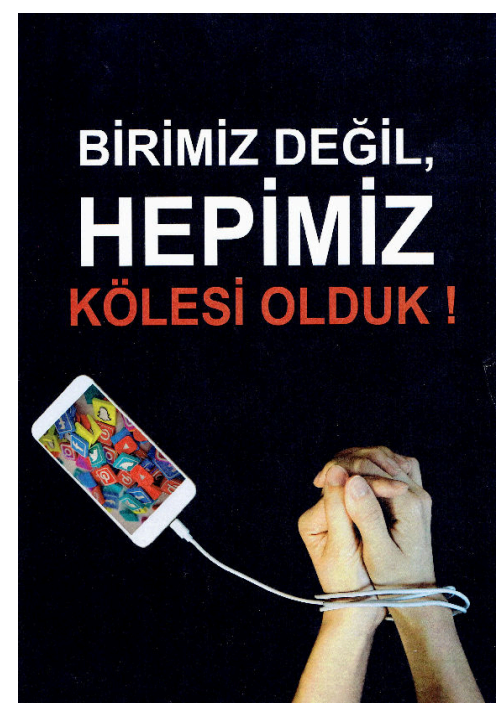

Öğrenci 20: "Çağımızda her yaş grubu insanların telefon, uygulama ve internete bağımlıdırlar. İnsanlar hayatlarının her anını gizli kalmaksızın gösterişli bir biçimde paylaşarak bu bağımlılığı sürdürmektedirler."

Afiş 20'de kullanıcıların sosyal medyanın kölesi olma konusu ele alınarak tasarımda siyah, beyaz ve kırmızı kullanılmıştır. Afişte şarj halinde bulunan bir telefon ve şarj kablosunun kelepçe görevinde bulunarak elleri bağlaması dikkat çekmektedir. Telefon ekranında ise Pinterest, YouTube, Twitter ve Facebook gibi sosyal medyanın birçok mecrasının logosu bulunmaktadır. Tasarımda yer alan "birimiz değil hepimiz kölesi olduk" söylemi ile kullanıcıların sosyal medyanın kölesi olduğu belirtilmektedir. 
Afiş 21

Kara delik

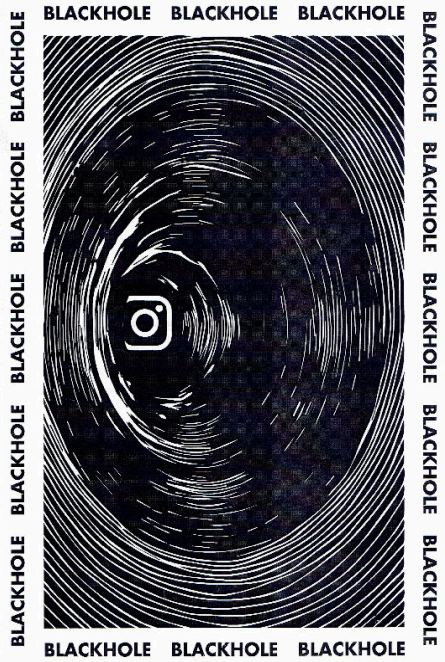

Öğrenci 21: "Instagram kullanıcıları içine çeken büyük bir kara delik. Uzay boşluğunda geçen zaman algılanmadığı gibi Instagram kullanırken de zaman algısı ortadan kalkmaktadır. Zamanı fark etmeden kullanılan bu ağ kullanıcılarda bağımlılığa yol açmaktadır."

Afiş 21'de Instagram'ın kullanıcılar üzerinde bir bağımlılık oluşturduğu ve kullanıcılar istemeseler dahi kendilerini içinde buldukları bir kara delik olduğu vurgusu yapılmaktadır. Bunun için siyah zemin üzerine beyaz çizgilerler farklı boyutlarda yuvarlaklar oluşturularak delik görüntüsü elde edilmiştir. Deliğin sonunda ise Instagram logosu görülmektedir. Tasarımın dört kenarında da "blackhole" yani kara delik yazısı yer almaktadır.

\subsubsection{Kimlik Oluşturma}

Afiş 22

Sosyal Medyada Mükemmelliyetçilik

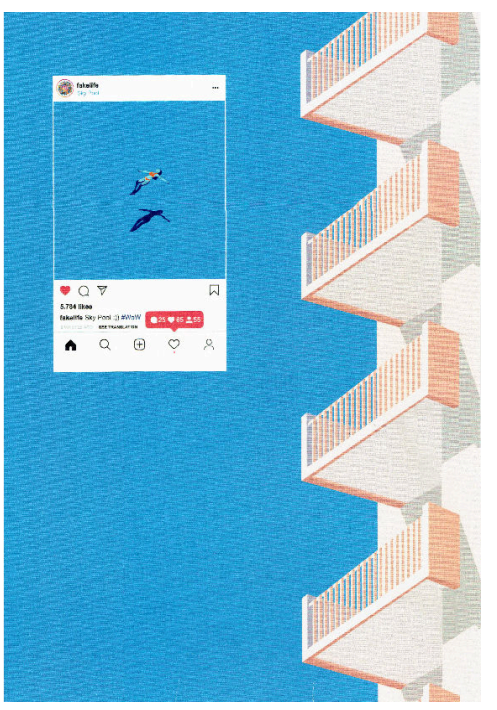

Öğrenci 22: "Sosyal medyanın önemli mecralarından biri olan Instagram kullanıcılarının genel özellikleri yaşamadıkları hayatı yaşamış gibi göstermeleridir. Bunun nedeni kendi yaşıtlarına veya kendinden büyük insanlara güzel görünme hissidir. Kullanıcıların çoğu kendilerini yüceltmek, gösteriş yapmak, egosunu tatmin etmek ve ünlü olmak için lüks hayata özenecek şekilde hikayeler ve gönderiler paylaşmaktadırlar. Unutulmamalıdır ki bu hayatların çoğu ekranda göründüğü gibi gerçek değildir."

Öğrenci yaptığı tasarımla Instagram'da karşılaşılan her gönderinin gerçeği yansıtmadığg, olayların ve yaşamların abartılarak takipçilere sunulduğunu anlatmıştır. Bunun için gökyüzünde uçabilen insan gönderisi oluşturularak görünenin arkasındaki gerçeklik sergilenmiş ve bu durumun mümkün olmadığı vurgusu yapılmak istenmiştir. 


\section{Afiş 23}

\section{İkiyüzlülük}

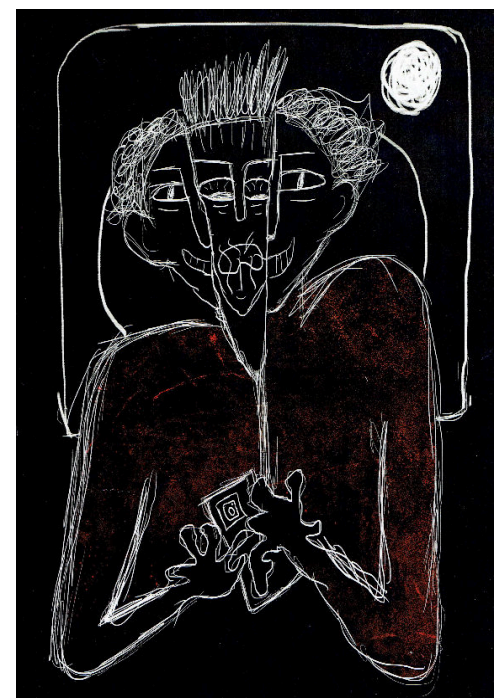

Öğrenci 23: "Tasarımda Instagram kullanıcılarının ikiyüzlülüğünü ele aldım. Kullanıcılar sosyal medyada kendilerini mutlu göstermeye çalışırken aslında kıskanç oldukları mesajını vermek istedim."

Afiş 23'te öğrenci, kullanıcıların Instagram'daki ikiyüzlü davranışlarını siyah zemin üzerine çizdiği elinde telefon bulunan insan figürüyle yansıtmaktadır. İnsan figürü görünenin arkasında olan farklı bir yüz ifadesiyle tamamlanarak mutluluk ve kıskançlık duygularının birbiri ardına gizlendiği görülmektedir. Bu durum kullanıcıların kıskançlıklarını gizleyerek mutlu gibi davranmalarını yani ikiyüzlülüklerini yansıtmaktadır. İnsan figürü tasarımı ortalayacak şekilde yerleştirilmiş̧ir.

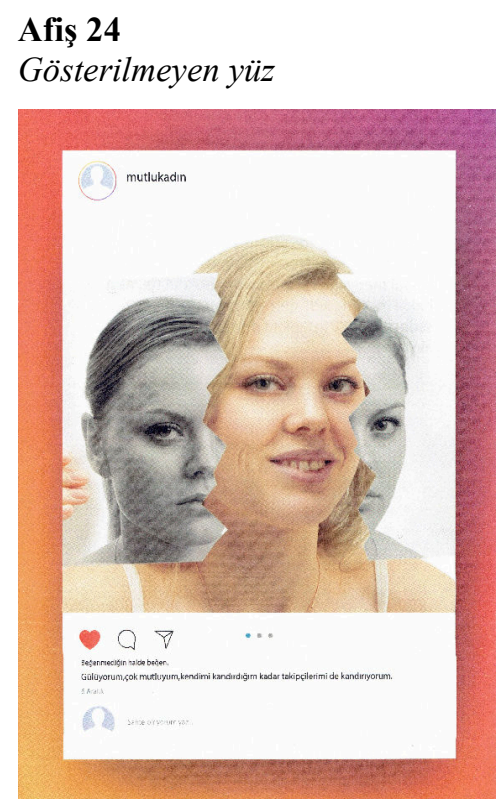

Öğrenci 24: "Instagram benim için insanların birbirine gösteriş yaptı̆̆ı, Mutlu değilken bile etrafa kendini mutlu gösterme çabasında olan insanların bulunduğu bir platformdur. Bu İnsanlar genellikle fenomen olmuş ve geçimini sosyal medyadan sağlayan kişilerdir."

İnsanlar sosyal medyada mutsuzluklarını paylaşmaktan sakınırlar. Özellikle sosyal medya üzerinden gelir elde etmek için ürün ve mekân tanıtan sosyal medya fenomenleri, takipçi kitlesine karşı mutlu görünme gereksinimi hissederler. Bu nedenle mutsuz olsalar dahi bunu gizleyerek mutlu rolü yapmaya çalışırlar. Bu durum sosyal medyada samimiyetin ve doğallığın ortadan kalkmasına yol açar. Bu afiş ile öğrenci, aslında mutsuz olan fakat mutlu rolü yapmaya çalışan kadın fotoğrafını Instagram gönderisi olarak tasarlamıştır. Gönderinin açıklama kısmında ise "Gülü̈yorum, çok mutluyum, kendimi kandırdığım kadar takipçilerimi de kandırıyorum." söylemi bulunmaktadır. 


\section{Sonuç}

- Araştırmaya katılan 40 öğrenciden 25'i Instagram'ı ele alan afiş tasarımları yapmışlardır. Çalışma grubu dikkate alındığında, çalışma grubunun \%62,5'inin afiş tasarımlarında Instagram'ı konu edindikleri görülmektedir. $\mathrm{Bu}$ bağlamda sosyal medyada en çok vurgulanan mecranın Instagram olduğu sonucuna varılmaktadır.

- Elde edilen veriler doğrultusunda öğrencilerin $\% 15$ 'i düşünceleri ifade etme, \%12,5'i günlük aktiviteleri paylaşma, \%7,5'i eğlence, \%10'u satış ve reklam, \%7,5'i olaylara dikkat çekme, \%7,5'i mesafeleri yok etme, $\% 15$ 'i bağımlılık, \%25'i kimlik oluşturma temalarını ile ele almıştır.

- Öğrencilerin yaptıkları afiş tasarımlarında "düşünceleri ifade etme” teması sosyal medyada düşünce özgürlüğünü ele almasına rağmen paylaşılan düşüncelerin diğer kullanıcılar üzerinde oluşturduğu olumsuz durumlar ve Twitter'ın sınırlı karakter sayıları gibi olumsuzluklar da ifade edilmiştir. "Günlük aktiviteleri paylaşma" temasında mahremiyet, göz önünde bulunma ve çeşitli yaşamların görülmesi gibi konular işlenmiştir. "Eğlence" temasında sosyal medyada yer alan içeriklerin fazlalığı, oyun ve iş hayatı ele alınmıştır. "Satış ve reklam" temalarında satış, marka ve tanıtımla ilgili afiş tasarımları bulunmaktadır. "Olaylara dikkatçekme" temasında toplumsal olaylar ve kullanıcıların bu olaylara karşı duyarsızlıkları ele alınmaktadır. "Mesafeleri yok etme"temasının yer aldığı afişlerde sosyal medya kullanıcılarının zaman ve maddi harcamalardan kaçınarak iletişim kurma imkanları konu edinilmiştir. "Bağımlılık" temasında kullanıcıların sosyal medyayı kontrolsüz kullanmaları ve sosyal medyanın bireyleri gerçek yaşamdan alı koyduğu fikirleri ele alınmıştır. "Kimlik oluşturma" temasında ise gösteriş, mükemmel yaşam, kullanıcıların beğeni ve takipçiye olan gereksinimleri ve ikiyüzlülük gibi konular yer almaktadır.

- Günümüzde sosyal medya birçok kullanıcı tarafından yaşamın çoğu alanında kullanılmaktadır. Bireylerin sosyal medyada yer alma amaçları birbirlerinden farklılık göstermektedir. Kullanıcılar sosyal medyayı gereksinimlerine göre kendilerini ifade etme, yaşamlarından anları paylaşma, eğlenme, satış ve reklam yaparak ekonomik gelir elde etme, sosyal olaylara dikkat çekme ve uzak mesafedeki kullanıcılarla iletişim kurma amaçları ile kullanabilmektedirler.

- Sosyal medyanın pek çok alanda kullanılmasının birey ve toplumlar üzerinde bazı etkileri bulunmaktadır. Gereksinimlerini sosyal medyada karşılamak isteyen kullanıcılar yüz yüze iletişimden uzaklaşarak sosyal medya bağımlısı durumuna gelirler. Bu durum kullanıcıların bazı değerlerini kaybetmelerine neden olabilir. Örneğin yüz yüze iletişimde jest ve mimiklerle söylenenlerin doğruluğu anlaşılabilirken sanal ortamda gerçekleştirilen iletişimde bu durumdan söz etmek mümkün değildir.

- Bazı kullanıcılar sosyal medyada kendilerine gerçekte var olan yaşantılarının dışında bir profil oluştururlar. Bu durum kullanıcıların kişilik gelişimlerini olumsuz etkiler.

- Araştırmaya katılan üniversite öğrencileri afiş tasarımlarında sosyal medyanın kullanıcılara sağladığı olumlu ve olumsuz etkilerini ele almışlardır.

- Çalışma grubundaki öğrencilerin yalnızca 2'si Facebook’u yansıtan afiş tasarımı yapmışlardır. Bu bağlamda $\% 5$ oranla en az vurgulanan sosyal medya platformunun Facebook olduğu sonucuna varılmaktadır.

Araştırma sonucuna göre belirlenen öneriler aşağıda yer almaktadır.

- Sosyal medyanın kullanıcılar üzerindeki etkilerine yönelik araştırmalar artırılmalı ve kullanıcılar bu konuda bilgilendirilmelidir.

- Bağımlılık düzeyinde olan sosyal medya kullanıcılarını bilinçlendirmek amacı ile çalışmalar yapılmalıdır.

- Sosyal medyanın kullanım amaçlarının olumlu yönlerine vurgu yapılmalı ve kullanıcılar yönlendirilmelidir.

\section{Kaynakça}

Akıncı Vural, Z. B., \& Bat, M. (2010). Yeni bir iletişim ortamı olarak sosyal medya: Ege Üniversitesi İletişim Fakültesine yönelik bir araştırma. Journal of Yasar University, 5(20), 33493356.https://dergipark.org.tr/tr/download/article-file/179294

Ambrose, G., \& Harris, P. (2012). Grafik tasarımın temelleri. İnk1lap Kitabevi.

Arslan, A. (2019). Ortaöğretim öğrencilerinin dijital bağımlılık düzeylerinin çeşitli değişkenler açısından incelenmesi: Sivas ili örneği. Gazi Eğitim Bilimleri Dergisi, 5(2), 6380.https://dergipark.org.tr/tr/download/article-file/771750

Bahar, A. (2018). Bilişim suçları, iletişim ve sosyal medya. İstanbul Aydın Üniversitesi Dergisi, 10(3), 136.https://dergipark.org.tr/tr/download/article-file/512739 
Becer, E. (2015). Illetişim ve grafik tasarım. Dost Kitabevi Yayınları.

Çakmak, S., \& Müezzin, E. (2018). Sosyal medya kullanımının iletişim becerileriyle ilişkisinin incelenmesi. Yeni Medya Elektronik Dergi, 2(3), 196-203.https://dergipark.org.tr/tr/download/article-file/514020

Çiftçi, H. (2018). Üniversite öğrencilerinde sosyal medya bağımlılı̆̆ı. MANAS Sosyal Araştırmalar Dergisi, 7(4), 417-434.https://dergipark.org.tr/tr/download/article-file/639146

Erözkan, A. (2009). Üniversite öğrencilerinin kişiler arası ilişki tarzları ve mizah tarzları. Dokuz Eylül Üniversitesi Buca Eğitim Fakültesi Dergisi, 26, 56-66.https://dergipark.org.tr/tr/download/article$\underline{\text { file } / 235044}$

Fidan, Z., \& Acar, Z. (2016). Sosyal medyada İletişim ve kadınlar üzerine bir değerlendirme. İnönü Üniversitesi İletişim Fakültesi Elektronik Dergisi, 1(2), 64-82.https://dergipark.org.tr/tr/download/article-file/716630

Kuyucu, M. (2014). Y kuşağı ve Facebook: Y kuşağının Facebook kullanım alışkanlıkları üzerine bir inceleme. Elektronik Sosyal Bilimler Dergisi, 13(49), 55-83.https://doi.org/10.17755/esosder.75785

Şimşek Yükselbilgili, N. (2016). Afiş tasarımında dikkate alınan kriterlerin algılanmasının analizi. Finans Ekonomi ve Sosyal Araştırmalar Dergisi, 1(1), 33-46.https://dergipark.org.tr/tr/download/article$\underline{\text { file } / 271605}$

Şimşek, T. (2019). Sosyal medyada mahremiyetin ifşası “Instagram örneğì”. Sosyolojik Düşün Dergisi, 4(1), 1024.https://dergipark.org.tr/tr/download/article-file/749128

Zinderen, İ. E. (2020). Yeni medya ekolojisi ekseninde Youtube: Türkiye örneği. Atatürk Üniversitesi Sosyal Bilimler Enstitüsü Dergisi, 24(1), 215-232.https://dergipark.org.tr/tr/download/article-file/1007669 